\title{
IBM SISWA YANG MENGHADAPI UJIAN NASIONAL BERBASIS KOMPUTER (UNBK)
}

\author{
Rio Wirawan ${ }^{1}$, M. Bayu Wibisono ${ }^{2}$ \\ ${ }^{1}$ Universitas Pembangunan Nasional veteran Jakarta \\ ${ }^{2}$ Universitas Pembangunan Nasional veteran Jakarta \\ Email: ${ }^{1}$ rio.wirawan@upnvj.ac.id, ${ }^{2}$ bayu.wibisono@upnvj.ac.id
}

\begin{abstract}
Abstrak: Di dalam era kemajuan teknologi, penggunaan komputer dapat di terapkan di diberbagai bidang khususnya di bidang pendidikan. Pengaplikasian komputer tersebut pada pembelajaran dan juga ujian. Penerapan ujian nasional sekolah menengah mulai diterapkan penggunaan komputer. Pelaksanaan ujian menggunakan komputer dimana siswa menjawab soal - soal ujian menggunakan computer. Dalam hal ini SMP terbuka Al Qalam adalah sekolah yang siswanya berasal dari kalangan menengah kebawah, yang sangat minim akan pengetahuan komputer. Untuk itu pengabdian kali ini memfocuskan kepada siswa/I Al Qalam untuk mengenalkan dan mengoprasikan komputer serta aplikasi komputer. Tujuan dari kegiatan ini adalah memberikan kepercayaan diri dan pengalaman serta wawasan bagi siswa/I SMP terbuka Al Qalam.
\end{abstract}

Kata Kunci: Ujian Nasional Berbasis Komputer, UNBK, Persiapan, Ujian Online, Aplikasi Komputer

\section{PENDAHULUAN}

Ujian nasional menjadi syarat kelulusan dari program pendidikan sekolah. Seiring perkembangan teknologi informasi ujian nasional dilakukan dengan menggunakan komputer. Penggunaan komputer untuk ujian nasional disebut CBT(Computer base system) atau sering disebut juga Unjian nasional Berbasis Komputer(UNBK). Hal ini membuat persiapan menempuh ujian nasional bertambah yakni selain mempelajari tentang materi yang diujikan, siswa juga harus mempelajari tentang teknologi komputer khususnya aplikasi komputer yang digunakan dalam ujian nasional.

Dalam mempersiapkan ujian nasional berbasis komputer siswa mempunyai cara yang beraneka ragam, salah satunya menurut firmansyah dengan melakukan pembiasaan dengan komputer yaitu dengan latihan langsung di depan komputer langsung dengan aplikasi yang serupa, namun siswa SMP terbuka AL Qalam tidak berkesempatan melakukan cara tersebut dikarenakan kondisi ekonomi.

Melalui pengabdian kepada masyarakat ini dilakukan pengenalan terhadap computer kepada siswa siswi SMP terbuka AlQalam. Sejalan dengan hasil penelitian rambe yang mengatakan adanya hubungan yang negatif yang berarti semakin tinggi dukungan maka semakin rendah kecemasan siswa dalam menghadapi ujian nasional. Selama pengabdian siswa akan dihadapkan dan dikenalkan langsung dengan komputer guna dapat menggunakan dan mengoprasikan komputer secara umum dan mengoprasikan aplikasi 
Jurnal Mediteg

Volume 3, Nomor 1, Desember 2018

komputer yang sesuai dengan pengoprasian

aplikasi ujian nasional berbasis komputer

\section{METODE PELAKSANAAN}

Siswa / siswi pada SMP terbuka $\mathrm{Al}$ Qalam ada 25 orang yang siap mengikuti ujian nasional. Namun mereka mempunyai kesulitan dalam beradaptasi dengan teknologi komputer dan dengan aplikasi ujian yang berbasis komputer, dikarenakan latar belakang dan kemampuan ekonomi yang tidak berkesempatan mencoba dan memahami teknologi komputer secara mandiri. Dalam kurikulum sekolah belum mempelajari tentang teknologi komputer secara khusus, hal ini menambah minimnya pengetahuan dan pengalaman siswa / siswi tersebut.

Peserta yang ditentukan adalah siswa/I SMP terbuka Al Qalam yang akan mengikuti ujian nasional berbasis komputer agar bekal dan materi yang didapatkan langsung dapat bermanfaat untuk ujian nasional berbasis komputer nantinya. Hal in seperti yang dikatakan oleh Mariskhana dimana faktor try out dan ujian nasional memberikan pengaruh positif dan signifikan terhadap kesiapan mental siswa. Peserta dari sekolah SMP terbuka AL Qalam sebanyak 15 Siswa. Siswa ini dipilih dari yang terdekat dengan pelaksanaan ujian nasional berbasis komputer.
p-ISSN : 2548-7655

e-ISSN : 2614-0489

Untuk melaksanakan pembekalan dan praktik pembiasaan dengan teknologi komputer dilakukan langkah - langkah sebagai berikut:

1. Identifikasi Awal terhadap pengetahuan komputer dan aplikasi komputer.

Pada tahap ini dilakukan wawancara terhadap kepala sekolah dan siswa/siswi secara langsung dengan cara tatap muka sebagai introduction materi dan memberikan semacam test pendahuluan (Pretest) untuk membuktikan lebih lanjut pengetahuan seputar penggunaan komputer.

2. Melakukan Analisis dan penentuan materi dan tools yang digunakan.

Pada tahap ini dilakukan analisis dan penentuan materi dan tools yang diperlukan, analisis dilakukan dari hasil wawancara dengan kepala sekolah, dan hasil tanya jawab saat tatap muka pertama, serta dari hasil test pendahuluan (pretest).

3. Melakukan penyampaian materi dan praktek.

Pada tahap ini dilakukan penyampaian materi kepada siswa siswa, penyampaian materi juga dengan melakukan praktek dan simulasi menggunakan aplikasi yang mirip dengan aplkasi ujian nasional berbasis komputer. Diharapkan siswa siswi nantinya memiliki 
Jurnal Mediteg

Volume 3, Nomor 1, Desember 2018

bekal dalam menempuh ujian nasional berbasis computer.

4. Melakukan evaluasi kegiatan.

Pada tahap ini dilakukan evaluasi kegiatan dengan cara memberi test akhir (post test) kepada siswa siswi sekolah terbuka Al Qalam.

5. Mengambil kesimpulan

Pada tahap ini dilakukan pengambilan kesimpulan dari kegiatan kegiatan yang telah dilaksanakan.

\section{HASIL KEGIATAN}

Sesuai dengan permasalahan yang dihadapi mitra yakni memberi bekal dan pemahaman kepada siswa siswi Al Qalam tentang tekonologi informasi untuk menghadapi ujian nasional berbasis komputer. Untuk melaksanakan kegiatan dan permasalahan diatas dilakukan langkah langkah sebagai berikut:

1. Identifikasi Awal terhadap pengetahuan komputer dan aplikasi komputer.

Wawancara dan diskusi kepada kepala sekolah dan mengasilkan harapan kepala sekolah adanya pembekalan konsep dan wawasan tentang komputer mengingat siswa siswi sekolah terbuka Al Qalam berasal dari kalangan menengah kebawah yang
p-ISSN : 2548-7655

e-ISSN : 2614-0489

jarang sekali berkesempatan mengetahui komputer dan didalam kurikulum sekolah tidak ada matapelajaran komputer. Kemudian dilakukan pretest dan wawancara langsung ke siswa dalam sesi tatap muka didalam kelas sebagai materi pendahuluan. Dari hasil wawancara dan pretest didapat siswa siswi tidak mengetahui definisi komputer dan pengoprasiannya, hal ini terlihat dari antusiasnya mereka mendengarkan dan terlihat gaptek dalam mengoprasikan komputer secara langsung. Sedangkan hasil pretest dihasilkan nilai rata - rata kelas sebesar 64.6 kemudian akan dibandingkan dengan hasil postest nantinya.

2. Melakukan Analisis dan penentuan materi dan tools yang digunakan.

Dari hasil wawancara diatas dianalisis untuk kebutuhan membuat dan merancang materi dan tools yang perlu digunakan. Untuk menjawab permasalahan diatas dibuat materi tatapmuka sebanyak 8 pertemuan dimana sudah termasuk 1 pertemuan pendahuluan. Sedangkan untuk tools yang akan digunakan adalah laptop, Proyektor LCD, software multimedia pembelajaran, dan website simulasi ujian nasional berbasis web. 
Jurnal Mediteg

Volume 3, Nomor 1, Desember 2018

3. Melakukan penyampaian materi dan praktek.

Penyampaian materi kepada siswa dilakukan dalam 8 pertemuan dimana penyampaian materi dilakukan 2 pertemuan, untuk praktek dan simulasi dimana dilakukan 4 pertemuan, 1 pertemuan dilakukan pretest dan pendahuluan, dan 1 pertemuan lagi dilakukan postest.

4. Melakukan evaluasi kegiatan.

Sebagai evaluasi belajar siswa sekolah terbuka Al Qalam dilakukan postest kemudian postest akan dibandingkan dengan hasil pretest untuk melihat perubahan yang ada. Diharapkan hasil postest lebih baik dari hasil pretest. Postest dilakukan test yang mengujikan dan mensimulasikan aplikasi ujian nasional berbasis komputer. Hasil dari postest ini diperoleh nilai rata - rata 71.5. kemudian nilai tersebut akan dibandingkan dengan hasil pretest, maka hal ini akan menjadi tolak ukur dalam keberhasilan dan evaluasi kegiatan ini.

5. Mengambil kesimpulan

Pada tahap ini dilakukan pengambilan kesimpulan dari kegiatan - kegiatan yang telah dilaksanakan, berdasarkan nilai rata -
p-ISSN : 2548-7655

e-ISSN : 2614-0489

rata pretest dan postest bila dibandingkan yaitu nilai pretest sebesar 64.6 sedangkan untuk postest dihasilkan nilai rata - rata sebesar 71.5 dari nilai rata- rata antara pretest dan postest terlihat nilai postest lebih besar dari nilai pretest hal ini menunjukan adanya penaikan nilai rata - rata kelas berdasarkan nilai pretest dan nilai postest.

\section{KESIMPULAN}

Berdasarkan kegiatan diatas dapat disimpulkan bahwa kegiatan pengabdian kepada masyarakat pada sekolah SMP terbuka AL Qalam telah meningkatkan wawasan dan pengetahuan siswa-siswi sekolah dalam penggunaan komputer khususnya untuk menghadapi ujian nasional berbasis computer, hal ini ditunjukan oleh siswa yang pada awalnya tidak mengerti definisi dan penggunaan komputer kemudian sejalan dengan pelatihan diberikan siswa semakin aktif dan antusias. Peningkatan ini juga ditunjukan dengan adanya peningkatan nilai rata - rata kelas berdasarkan test pendahuluan dan Post test yang dilakukan denngan aplikasi yang mirip dengan ujian nasional yang berbasis komputer nantinya. Dengan demikian Persiapan siswa - siswi SMP Terbuka Al-Qalam semakin baik persiapannya untuk menghadapi ujian nasional berbasis 
Jurnal Mediteg

Volume 3, Nomor 1, Desember 2018

komputer(UNBK) dan meningkatkan

kepercayaan diri siswa tersebut.

\section{DAFTAR PUSTAKA}

Aplikasi Gratis Online UNBK. https:/ /cbt.hasama.co.id/ Januari 2017

Firmansyah, Ada Udi. “Aplikasi Simulasi Uji

Coba (Tryout) Ujian Nasional Berbasis

Komputer (Unbk) Tahun 2018"

Seminar Nasional Royal (SENAR) 2018, hlm. 111 - 114 ISSN 2622-6510, Kisaran, Asahan, Sumut - September 2018

HM, Jogiyanto. Analisa dan Desain Sistem Informasi. Andi Offset Yogyakarta: 2015

HM, Yogiyanto. Pengenalan computer (PK).

Informatika. 2015

Mariskhana, Kartika. "Pengaruh Tryout Dan Ujian Nasional Berbasis Komputer Terhadap Sikap Mental Siswa Pada Mts Al-Makmur Parung Panjang" Jurnal AKRAB JUARA Volume 3 Nomor 4 Edisi November 2018(222-234)

Narbuko, Cholid. (2013). Metodologi Penelitian. Jakarta : PT Bumi Aksara. Hal 76

Nyura, Yusni. Pembuatan Aplikasi Pembelajaran Bahasa Inggris pada Handphone dengan J2ME. Jurnal Ilmiah ilmu Komputer Informatika Mulawarman Vol 5, No. 3.

Rambe, Yuni Sarjani. "Hubungan Self Efficacy Dan Dukungan Sosial Dengan Kecemasan Siswa Menghadapi Ujian Nasional Berbasis Komputer (UNBK) Di SMK Swasta PAB 12 Saentis” Jurnal
p-ISSN : 2548-7655

e-ISSN : 2614-0489

Analitika, Vol. 9 (1) p-ISSN : 2085-6601

e-ISSN : 2502-4590 Juni (2017)

Ujian Nasional Berbasis Komputer 2017/2018https://unbk.kemdikbud.go .id/tentang\#content November 2018 